\title{
Grażyna Gzella
}

Instytut Informacij Naukowej i Bibliologii Uniwersytet Mikołaja Kopernika w Toruniu e-mail: gmg@umk.pl

\section{Kłopoty $\mathbf{z}$ prawem zapomnianych gazet pomorskich (1910-1915)}

DOI: $10.12775 /$ TSB.2013.027

STreSZCZEnIE: W początkach XX w. oferta skierowana do Polaków Prus Zachodnich znacznie się powiększyła. W mniejszych miejscowościach, poza Gdańskiem, Toruniem czy Grudziądzem, powstały gazety skierowane do mieszkańców Starogardu Gdańskiego, Chojnic, Świecia i Lubawy oraz okolicznych wsi, zawierające informacje z kraju, prowincji, najbliższego regionu i miasta. Redakcje „Naszej Gazety”, „Gazety Chojnickiej”, „Gazety Świeckiej” i „Głosu Lubawskiego” w krótkim czasie swego istnienia zetknęły się z niemieckim wymiarem sprawiedliwości. Redaktorom odpowiedzialnym tych periodyków wytoczono 11 procesów, w trakcie których oskarżono ich m.in. o obrazę i podburzanie do gwałtów. W rezultacie redakcje musiały zapłacić blisko dwa tysiące marek kary finansowej, a przed sądem znalazło się siedmiu redaktorów.

Słowa kluczowe: „Gazeta Chojnicka”, „,Gazeta Świecka”, „Głos Lubawski”, „Nasza Gazeta”, 1910-1915, gazety pomorskie, procesy prasowe.

W drugim dziesięcioleciu XX w. oferta prasowa skierowana do Polaków Prus Zachodnich znacznie się powiększyła. Kształtowany od 1848 r. system prasy został poszerzony o periodyki prowincjonalne, tworzone w mniejszych miastach, nieposiadających dotychczas własnych, polskojęzycznych wydawnictw prasowych. 
Silnym ośrodkiem prasowym w początkach XX w. stał się Starogard Gdański ${ }^{1}$, w którym 17 września 1910 r. ukazał się numer okazowy „Naszej Gazety”. Nakładcą i drukarzem periodyku był Leon Kowalski², a pierwszym redaktorem odpowiedzialnym Alojzy Bieliński ${ }^{3}, \mathrm{z}$ czasem odpowiedzialność za redakcję przejęli Feliks Kisielewski ${ }^{4}$ i ponownie Kowalski. Pierwszy numer wydano z datą 1 października ${ }^{5}$. Pismo ukazywało się trzy razy w tygodniu i miało mutacje: „Gazetę Brodnicką”, , Gazetę Kościerską" i „Gazetę Lubawską"6.

Kolejnym miastem, w którym utworzono polską gazetę w początkach XX w., były Chojnice. Dnia 15 marca 1912 r. wydano numer okazowy „Gazety Chojnickiej”", zapowiadając, że numer pierwszy ukaże się 1 kwietnia ${ }^{8}$. Pismo nie zachowało się, stąd stosunkowo wiele wątpliwości

${ }^{1}$ Scharakteryzowano tylko te gazety, które w okresie od 1910 do 1915 r. zetknęły się z niemieckim wymiarem sprawiedliwości.

2 Szerzej zob. A. Siemiginowska, Kowalski Leon, [w:] Polski słownik biograficzny, t. 14, Wrocław 1968-1969, s. 54-55. Tam błędna informacja, że Kowalski związany był z „Gazetą Grudziądzką", podczas gdy w redakcji tego pisma pracował inny Leon Kowalski.

${ }^{3}$ Alojzy Bieliński (1889-1916) pochodził z Pączewa. Uczył się w Collegium Marianum w Pelplinie, a potem w Toruniu. Z wykształcenia był drukarzem. Po pracy w „Naszej Gazecie” wyjechał do Nadrenii, gdzie w Oberhausen, tuż przed wybuchem pierwszej wojny światowej, założył drukarnię. Powołany na front zamknął swe przedsiębiorstwo. Zmarł w lazarecie polowym w wyniku ran odniesionych na froncie we Francji. Zob. np.: M. Pestka Garnyszowa, Pączewo z dziejów i obyczaju wsi kociewskiej, Tczew 1989, s. 103, 110; [Nekrolog], „Pielgrzym” 1916, nr 68, s. [4].

4 Informacja o redagowaniu „Naszej Gazety” przez Feliksa Kisielewskiego zob. Wiadomości z naszych i dalszych stron, „Gazeta Grudziądzka” 1912, nr 110, s. [2]. F. Kisielewski (1867-1931) pochodził z Torunia. Z wykształcenia był zecerem. Zawodu uczył się u Józefa Buszczyńskiego. Po krótkiej zapewne pracy w Starogardzie powrócił do rodzinnego miasta, gdzie dalej pracował w wyuczonym zawodzi. Zob. Wiadomości potoczne, „Słowo Pomorskie"1931, nr 161, s. 8.

5 O fakcie tym poinformowały polskie gazety. Zob. „Gazeta Toruńska” 1910, nr 177, s. [2]; „Gazeta Olsztyńska” 1910, nr 92, s. [2]; „Gazeta Bydgoska” 1910, nr 191, s. [2], nr 215, s. [3].

${ }^{6}$ Bibliografia historii Polski XIX i XX wieku, t. 3: 1865-1918, wol. 2, Warszawa 2010, s. 339; J. Banach, Powstanie i rozwój polskiej prasy w Starogardzie Gdańskim w końcowym okresie rozbiorów, [w:] Pomorze. Okno na świat. Studia z dziejów XIX i XX wieku, Gdańsk 2002, s. 39-40.

7 Bibliografia historii..., s. 277.

8 Zob. Nasze sprawy, „Orędownik” 1912, nr 65, s. [2]; Polska, „Gazeta Lipska” 1912, nr 35, s. [2]; Wiadomości potoczne, „Pielgrzym” 1912, nr 35, s. [2]. 
dotyczących jego twórców. Współczesna prasa podała, że w chwili powstania gazeta związana była z pelplińskim „Pielgrzymem”, a wydawcą był bliżej nieznany Stanisław Owsiany ${ }^{10}$. W lipcu 1912 r. „Gazeta Chojnicka” uzyskała samodzielność, przestała być uzależniona od pelplińskiego pisma, a jej redaktorem odpowiedzialnym został Edmund Rakowski ${ }^{11}$, który już pod koniec tego roku przeniósł się do Świecia i tam redagował „Gazetę Świecką". Na stanowisku redaktora odpowiedzialnego „Gazety Chojnickiej” zastąpił go Antoni Konieczny ${ }^{12}$.

Wspomniana „Gazeta Świecka” pojawiła się 24 grudnia 1912 r. (numer okazowy). Ukazywała się trzy razy w tygodniu, pod redakcją znanego dziennikarza Mieczysława Noskowicza ${ }^{13}$, który w Świeciu pracował zaledwie kilka miesięcy, bo już w marcu 1913 r. redakcja poszukiwała nowego redaktora ${ }^{14}$. Został nim drukarz Teofil Zieliński ${ }^{15}$ związany z „Gazetą Grudziądzką". Wkrótce też do redakcji świeckiego pisma trafił z redakcji „Gazety Chojnickiej” E. Rakowski. Świecki periodyk posiadał dwie mutacje: „Gazetę Chełmińską” i „Gazetę Chełmżyńską”.

"Głos Lubawski” to ostatnia gazeta Prus Zachodnich powstała przed I wojną światową, której numer okazowy opublikowano 18 marca $1913 \mathrm{r}$. Pierwszym redaktorem odpowiedzialnym był całkowicie nieznany Ludwik Jabłoński, następnie stanowisko to zajmowali Józef Alojzy Gawrych ${ }^{16}$,

9 Zob. np.: Sprawy polskie, „Dziennik Bydgoski” 1912, nr 63, s. [1].

10 Stanisław Owsiany żył w latach 1870-1915. Archiwum Diecezjalne w Pelplinie, Parafia w Czersku, Liber baptisatorum 1870; tamże, Parafia w Rytlu, Liber mortuorum 1899-1950.

11 Wiadomości potoczne, „Dziennik Bydgoski” 1912, nr 154, s. [3]; Z różnych stron, „Dziennik Poznański” 1912, nr 156, s. [4].

12 Antoni Konieczny (1887-1940) był już doświadczonym dziennikarzem. Wcześniej pracował w „Głosie Śląskim”, „Lechu” i „Gazecie Gdańskiej”. Bibliografia historii..., indeks. O jego obecności w redakcji „Gazety Chojnickiej” zob. np.: Polska, „Przyjaciel” 1913, nr 4, s. [2].

13 S. Poręba, Noskowicz Mieczysław, [w:] Polski słownik biograficzny, t. 23, Wrocław 1978, s. 218.

14 [Anons], „Pielgrzym” 1913, nr 34, s. [3].

15 Archiwum Państwowe w Poznaniu [dalej cyt.: AP Poznań], Prezydium Policji [dalej cyt.: PP], sygn. 3787.

16 Zob. np.: Tobie Polsko. Szkice biograficzne działaczy ruchu niepodległościowego na Górnym Śląsku, pod red. W. Lesiuka, W. Zielińskiego, Opole 1981, s. 147-153. 
Wiktor Ujma ${ }^{17}$, Stefan Podkomorski ${ }^{18}$, a pod koniec wojny Mieczysław Piechowski ${ }^{19}$.

Redakcje wszystkich wymienionych tytułów dostarczały swym czytelnikom bieżące informacje z kraju, prowincji, najbliższego regionu i miasta, a gazety swą strukturą przypominały inne wydawnictwa ciągłe wydawane w tym czasie w zaborze pruskim, informowały, uczyły i kształtowały świadomość.

Oprócz „Głosu Lubawskiego”, który przetrwał lata wojny, oraz „Głosu Ludu”, który przestał się ukazywać w lipcu 1912 r., pozostałe wymienione pisma znikły z rynku prasowego w początkowych miesiącach pierwszej wojny światowej.

Przepisy prawne obowiązujące tak polskich, jak i niemieckich redaktorów odpowiedzialnych w początkach XX w. uchwalone zostały wraz z powstaniem Drugiej Rzeszy Niemieckiej. Nowy Kodeks karny ukazał się 15 maja 1871 r. i był przeróbką kodeksu z 1851 r. Znalazły się w nim paragrafy mające zastosowanie w procesach prasowych. Dnia 7 maja 1874 r. wydano „Ustawę prasową” (weszła w życie 1 lipca tego roku), której § 1 głosił: „Wolność prasy podlega tylko tym ograniczeniom, które przepisane są, względnie dozwolone niniejszą ustawą"20. W kraju obowiązywała kontrola represyjna, niepozwalająca na kontrolowanie treści przed ich wydrukowaniem, ponieważ: „odpowiedzialność za czyny, których karygodność jest uzasadniona na podstawie treści druku, normują istniejące ogólne prawa karne. W piśmie periodycznym redaktor odpowiedzialny będzie karany jako sprawca, o ile wyjątkowe okoliczności nie

17 W lipcu 1914 r. był już byłym redaktorem „Głosu”. Prawdopodobnie to on w $1919 \mathrm{r}$. redagował czasopismo „Kinematograf Polski”, następnie pracował w redakcjach „Orędownika” „ „Kuriera Poznańskiego”. M. Hendrykowska, Czasopiśmiennictwo filmowe w Poznaniu w latach 1918-1939, „Kronika Miasta Poznania”, 48: 1980, s. 42.

18 Stefan Podkomorski (1878-1935) z wykształcenia był prawnikiem. W redakcji „Głosu” pracował od 1 lipca 1914 r., ale już w marcu 1915 r. został powołany do wojska i zatrudniony na stanowisku cenzora w Wydziale Prasowym przy Generał-Gubernatorstwie Warszawskim. Po wojnie był kierownikiem Wojskowego Sądu Rejonowego w Poznaniu. Zob. AP Poznań, USC Obrzycko, sygn. 13; tamże, PP, sygn. 4982; Zgony, „Dziennik Poranny" 1935, nr 231, s. 6.

19 Z. Kratochwil, Piechowski Mieczysław, [w:] Słownik biograficzny Pomorza Nadwiślańskiego, t. 3, Gdańsk 1997, s. 413-414.

20 Dzielnica pruska. Ustawa prasowa z dnia 7 maja 1874 r., [w:] S. Lam, Przepisy prasowe i widowiskowe obowiq̨zujące w granicach państwa polskiego, Warszawa 1921, s. 94. 
wykluczają jego przestępstwa"21. Każdy numer gazety musiał zawierać nazwisko redaktora odpowiedzialnego, który odpowiadał za wszystkie treści umieszczone w danym numerze, stąd nazywano go „redaktorem od siedzenia” czy „redaktorem od kozy”22.

Spośród redaktorów odpowiedzialnych wszystkich wymienionych periodyków z niemieckim wymiarem sprawiedliwości najwcześniej zetknął się redaktor „Naszej Gazety”23 Alojzy Bieliński. W styczniu 1911 r. na łamach periodyku Kowalskiego przedrukowano z „Pielgrzyma” korespondencję z Sulęczyna ${ }^{24}$, której autor skrytykował działania administratora tamtejszej parafii ${ }^{25}$ księdza Jana Pawła Aeltermanna ${ }^{26}$. Księdzu zarzucono brak znajomości języka polskiego, usuwanie z kościoła niektórych parafian i ograniczanie do niego dostępu. Wreszcie zauważono, że skutkiem takiego postępowania księdza stało się przechodzenie na religię ewangelicką. Nie znamy przebiegu procesu w Starogardzie, podczas którego osądzono Bielińskiego, ale gdy miesiąc później za ten sam artykuł sądzono redaktora odpowiedzialnego „Pielgrzyma” świadkowie wydarzeń w Sulęczynie potwierdzili większość wypadków opisanych w publikacji. Mimo to osoby podpisujące numery polskich gazet zawierających inkryminowaną korespondencję zostały skazane ${ }^{27}$, a wyroki były stosunkowo

21 Tamże, s. 101.

22 Szerzej zob. G. Gzella, Pruskie prawo prasowe w drugiej połowie XIX wieku, [w:] W kręgu prasy (przeszłość - teraźniejszość - przyszłość), t. 2, pod red. G. Gzelli, J. Gzelli, Toruń 2001, s. 33-43; taż, „Przed wysokim sq̨dem”. Procesy prasowe polskich redaktorów czasopism dla chłopów w zaborze pruskim, Toruń 2004, s. 30-38.

${ }^{23}$ Egzemplarze czasopism, w których zamieszczono inkryminowane artykuły nie zachowały się, stąd podjęto próbę scharakteryzowania ich, opierając się na tekstach zamieszczonych w innych gazetach, których redaktorzy odpowiedzialni mieli również procesy, niewątpliwie za te same treści.

${ }^{24}$ Tekst ten pojawił się również w innych polskich gazetach Prus Zachodnich, stąd znamy jego treść. Zob. np.: Wiadomości potoczne, „Pielgrzym” 1911, nr 6, s. [1].

25 Proboszczem sulęczyńskiej parafii był Polak ksiądz Antoni Weilandt, któremu władze duchowne odebrały zarząd nad sprawami majątkowymi parafii pozostawiając w jego rękach sprawy duchowne. Wywołało to zatargi, które w rezultacie doprowadziły do odsunięcia Weilandta od spraw parafii i przeniesienie go do „domu księży wysłużonych” w Zamartem. Zob. Półtora tysiąca marek kary za obrazę księdza, „Gazeta Toruńska” 1911, nr 173, s. [1]; o osobie proboszcza zob. H. Mross, Słownik biograficzny kapłanów diecezji chełmińskiej wyświęconych w latach 1821-1920, Pelplin 1995, s. 349.

${ }^{26}$ Zob. H. Mross, dz. cyt., s. 1.

27 Ignacego Wieczorka redaktora „Pielgrzyma” skazano na karę finansową w wyso- 
wysokie. W przypadku „Naszej Gazety”, której redaktor zrzekł się obrony, sąd okazał się być surowszy od prokuratora. Podczas gdy oskarżyciel za obrazę $^{28}$ księdza Aeltermanna wniósł o karę finansową dla Bielińskiego $^{29}$ wynoszącą 150 marek, sąd nakazał redaktorowi zapłacić aż 600 marek $^{30}$ lub w razie gdyby nie mógł wnieść takiej kwoty 100 dni więzienia ${ }^{31}$. Skarżący duchowny w trakcie procesu pod żadnymi warunkami nie chciał zgodzić się na ugodę. Jego zdaniem autorem korespondencji był poprzedni proboszcz parafii ks. Weilandt, jak zauważył „Polak, mimo niemieckiego nazwiska ${ }^{32}$ ”. Relacja z procesu zamieszczona w „Naszej Gazecie" wywołała kolejne niezadowolenie duchownego i wkrótce czytelnicy dowiedzieli się, że ksiądz wytoczył redakcji następny proces o obrazę ${ }^{33}$. Nie zachowały się żadne informacje o przebiegu i rezultacie tego procesu, ale rzecz nie była odosobniona. Drugi i kolejne procesy, w których sądzono polskich redaktorów odpowiedzialnych za obrazę Aeltermanna, wytoczono również redakcjom „Pielgrzyma”34, „Gazety Grudziądzkiej”35 i „Gazety Gdańskiej”. Redakcja tej ostatniej poinformowała w maju 1912 r.: „trzy tysiące przeszło marek kary, naznaczono kilku innym pismom naszej dzielnicy - a teraz naszemu redaktorowi p. Grimsmannowi trzy miesiące i tydzień więzienia”, i dalej zaznaczyła „Procesy te dla historyka,

kości 1500 marek. [Na 1500 marek kary pieniężnej lub 5 miesięcy więzienia], „Pielgrzym” 1911, nr 91, s. [1]. Wywołało to komentarze prasy polskiej i kolejne procesy.

${ }^{28}$ W Kodeksie karnym obrazy dotyczyły trzy paragrafy: 185, 186 i 187. Zob. Kodeks karny Rzeszy Niemieckiej z dnia 15 maja 1871 r. z późniejszymi zmianami i uzupełnieniami po rok 1918 wraz z ustawą wprowadczq do kodeksu karnego dla Zwiq̨zu Północno-Niemieckiego (Rzeszy Niemieckiej) z dnia 31 maja 1870 r., Poznań 1920, s. 82-83.

${ }^{29}$ Kronika sq̨dowa, „Dziennik Poznański” 1911, nr 151, s. [3].

${ }^{30}$ Informowały o tym liczne gazety polskie. Zob. np.: Polska, „Gazeta Toruńska” 1911, nr 149, s. [2]; Nasze sprawy, „Pielgrzym” 1911, nr 79, s. [2]; Sprawy polskie, „Dziennik Bydgoski” 1911, nr 150, s. [2]; Nasze sprawy, „Kurier Poznański” 1911, nr 150, s. [5].

31 Sądy niemieckie wydając wyroki brały pod uwagę niemożność zapłacenia kary finansowej przez oskarżonego i w zamian określały czas pobytu w więzieniu.

32 Sprawy polskie, „Dziennik Bydgoski” 1911, nr 150, s. [2].

33 Nasze sprawy, „Dziennik Kujawski” 1911, nr 164, s. [2].

${ }^{34}$ Zob. np.: Wiadomości potoczne, „Pielgrzym” 1911, nr 98, s. [3]; Przed izbq karnq w Starogardzie, „Pielgrzym” 1912, nr 5, s. [3]; Na tysiąc marek grzywny lub 100 dni więzienia, „Pielgrzym” 1912, nr 26, s. [2]; Znowu na 1000 mr. Grzywny lub 100 dni więzienia, „Pielgrzym” 1912, nr 32, s. [1].

35 Szerzej zob. G. Gzella, Procesy prasowe redaktorów „Gazety Grudziądzkiej” w latach 1894-1914, Toruń 2010, s. 131-132. 
który kiedyś o naszych stosunkach kościelnych w Prusach Zachodnich podejmie się pisać, będą miały ogromne znaczenie" 36 .

Przez pewien czas redaktorem odpowiedzialnym „Naszej Gazety” był F. Kisielewski, którego również nie ominął proces prasowy. We wrześniu 1912 r., byłego już redaktora sąd starogardzki, za wydrukowanie odezwy zatytułowanej Pomoc dajcie nam rodacy, skazał na 50 marek grzywny. Prokurator w akcie oskarżenia domagał się kary w wysokości 75 marek $^{37}$. Tę samą odezwę opublikowano w „Gazecie Chojnickiej”38, której redaktorem w lipcu 1912 r., gdy prokurator rozpoczął postępowanie sądowe, był E. Rakowski. Rzecz dotyczyła zbierania składek na rodziny Polaków zasądzonych w procesie świeckim. Nie znamy przebiegu obu procesów, ale wiadomo, że odezwa opublikowana w „Naszej Gazecie” i „Gazecie Chojnickiej” była wynikiem innego, świeżo zakończonego procesu, wytoczonego szesnastu mieszkańcom Świecia, którzy jakoby dopuścili się podburzania do gwałtów po przegranych wyborach do parlamentu w dniu 26 stycznia 1912 r. Rzeczywiście w tym czasie doszło w mieście do rozruchów, będących efektem, jak napisano w „Gazecie Toruńskiej”, „nadużyć jakich dopuszczali się Niemcy w wyborach" ${ }^{39}$. Po procesie świeckim redakcje „Naszej Gazety” i „Gazety Chojnickiej”, podobnie jak wspomniana „Toruńska" ${ }^{\prime \prime}$, zauważyły, że rodziny oskarżonych pozostających od czterech miesięcy w więzieniu są bez środków do życia, stąd komitet, celem którego będzie zbieranie składek na pomoc. Proces „Naszej Gazety” toczył się we wrześniu, a „Gazety Chojnickiej” w listopadzie 1912 r. Prokurator zarzucił redaktorom wzywanie do składek, które miałyby pokryć koszty procesu świeckiego, a nie wspomóc rodziny skazańców ${ }^{41}$ i chociaż $\mathrm{w}$ trakcie po-

36 Trzy miesiące i tydzień więzienia za obrazę księdza Aeltermanna, „Gazeta Gdańska” 1912, nr 53, s. [1].

37 Wiadomości z naszych i dalszych stron, „Gazeta Grudziądzka” 1912, nr 110, s. [2]; Wiadomości miejscowe i prowincjonalne , „Postęp” 1912, nr 207, s. [3].

${ }^{38}$ Polska, „Gazeta Toruńska” 1912, nr 158, s. [1]; Sprawy polskie, „Dziennik Bydgoski” 1912, nr 158, s. [1]; Nowy proces świecki, „Przyjaciel” 1912, nr 85, s. [2]; Wiadomości z bliska i z daleka, „Wielkopolanin” 1912, nr 159, s. [3]; Polska, „Gazeta Lipska” 1912, nr 86, s. [3]; Nasze sprawy, „Orędownik” 1912, nr 160, s. [2].

39 Po wyroku świeckim, „Gazeta Toruńska” 1912, nr 126, s. [1].

40 Prawdopodobnie informacja podana przez redakcję „Gazety Toruńskiej” była napisana w łagodniejszej formie, nie doszło bowiem do procesu.

${ }^{41}$ Wiadomości potoczne, „Dziennik Bydgoski” 1912, nr 272, s. [3]. Prokurator w swym oskarżeniu zastosował $\S 16$ prawa prasowego, który brzmiał: „Publiczne wezwania w prasie do składania gotówkowych datków, na pokrycie kar pieniężnych, nałożonych 
siedzenia redaktor „Gazety Chojnickiej” E. Rakowski przekonywał, że odezwa była podpisana przez prawników, a on nie wiedział, że dopuszcza się czynu karygodnego, prokurator wniósł również dla niego o karę finansową wynoszącą 150 marek, a sąd zmniejszył wyrok do 80 marek $^{42}$. W ten sposób jedna opublikowana odezwa uszczupliła finanse dwóch redakcji łącznie o 130 marek.

Po Kisielewskim, w końcu 1912 r., „Naszą Gazetę” podpisywał wydawca i drukarz pisma L. Kowalski, który w lutym 1913 r. zamieścił w swym piśmie oświadczenie: „Zawartą w nr 132 redagowanej przeze mnie «Naszej Gazety» obrazę tutejszej policji w sprawie Towarzystwa Młodzieży Katolickiej z ubolewaniem cofam i płacę do tutejszej kasy ubogich 300 marek grzywny"43. Musiało to być efektem nieznanego bliżej procesu, o czym świadczy grzywna, a nie np. dobrowolna wpłata będąca wynikiem ugody.

Kłopoty prawne redakcji „Gazety Chojnickiej” zaczęły się już w kilka miesięcy po powstaniu periodyku, jeszcze przed procesem o wspomnianą już odezwę. Jak poinformowała redakcja w sierpniu 1912 r., a za nią tekst ten powtórzyły liczne gazety pomorskie, wielkopolskie i śląskie (stąd znamy jego treść):

Policja tutejsza od samego początku istnienia naszej drukarni jest naszym częstym gościem. Wczoraj odwiedził nas znowu policjant i z polecenia komisarza policji chojnickiej oświadczył, żeby naszą firmę sądownie zatwierdzoną i umieszczoną na naszym domu, przeinaczyć. Na zapytanie w jaki sposób to uczynić, delegat pana komisarza chojnickiego objaśnił, że nagłówek „Gazeta Chojnicka” ma brzmieć „Koenitzer Zeitung”44.

na kogoś za przestępstwa, jako też publiczne potwierdzanie odbioru składek na taki cel, są zabronione". Dzielnica pruska..., s. 99-100.

42 Wiadomości potoczne „Pielgrzym” 1912, nr 143, s. [3]; Wiadomości z bliska i z daleka, „Wielkopolanin” 1912, nr 272, s. [3]; Nasze sprawy, „Orędownik” 1912, nr 274, s. [2].

43 Oświadczenie, „Gazeta Lubawska” 1913, nr 17, s. 1.

${ }^{44}$ Cyt. za: Z różnych stron, „Dziennik Poznański” 1912, nr 182, s. [3]; Polska, „Gazeta Toruńska” 1912, nr 184, s. [2]; Wiadomości z bliska i z daleka, „Wielkopolanin” 1912, nr 184, s. [3]; Wiadomości miejscowe i prowincjonalne „Postęp” 1912, nr 182, s. [2]; Mowa posła dr Zygmunta Seydy, „Postęp” 1913, nr 31, s. [1]; Ciekawe żądanie policyi, „Kuryer Śląski” 1912, nr 183, s. [2]; Z całego świata, „Katolik” 1912, nr 99, s. [2]. 
Gazeta niemiecka o tym tytule istniała już w mieście i zapewne nie doszło do umieszczenia niemieckojęzycznej tablicy na budynku redakcji, ale żądania urzędników niemieckich nie zakończyły się, bowiem kilka dni później policjant, na życzenie landrata powiatu chojnickiego, polecił aby na budynku wypisać nazwiska wszystkich członków Spółki Wydawniczej „Gazety Chojnickiej”. Fakt ten redakcja skomentowała: „Trudno odgadnąć przyczynę tego niezwykle ciekawego życzenia. A jeszcze trudniej odnaleźć odpowiednie przepisy prawne. [..] Widocznie musiało zajść znowu przeoczenie jakiegoś przepisu lub też nieporozumienie, o co w ciągłej walce $\mathrm{z}$ «niebezpieczeństwem polskim» wcale nie trudno"45. Nie wiemy o jakie przeoczenie chodziło, być może urzędnicy administracji niemieckiej zrezygnowali z dalszego nękania redakcji, w żadnej gazecie zaboru pruskiego nie wrócono bowiem do tej kwestii.

Również „Gazeta Świecka”, w swej niezbyt długiej historii, nie ustrzegła się kłopotów prasowych. W kwietniu 1913 r. zamieszczono w piśmie korespondencję relacjonującą przebieg wiecu w Świeciu, podczas którego przemówienie wygłosił redaktor „Dziennika Bydgoskiego”. Pierwsze przesłuchanie T. Zielińskiego, redaktora świeckiego pisma, odbyło się w pierwszych dniach czerwca. Prokurator twierdził, że w opublikowanej korespondencji usiłowano podburzyć mieszkańców miasta przeciwko rządowi pruskiemu ${ }^{46} \mathrm{w}$ celu, jak stwierdzono, „oderwania dzielnic polskich od granic pruskich" ${ }^{\prime 7}$. Sędziowie podczas procesu we wrześniu potwierdzili zarzuty oskarżyciela. Redaktora skazano na karę finansową wynosząca 400 marek lub 40 dni więzienia, gdyby skazany nie był w stanie zapłacić tej kwoty ${ }^{48}$. Łącznie z kosztami postępowania sądowego kara wyniosła 490 marek $^{49}$.

45 Wiadomości z bliska i z daleka, „Wielkopolanin” 1912, nr 196, s. [3]; Nasze sprawy, „Orędownik" 1912, nr 194, s. [2]; Wiadomości miejscowe i polityczne, „Postęp” 1912, nr 196, s. [3]; Z różnych stron, „Dziennik Poznański” 1912, nr 193, s. [4]; Polska, „Gazeta Toruńska" 1912, nr 194, s. [1].

46 Podburzania do gwałtów dotyczył §130 Kodeksu karnego. Zob. Kodeks karny..., s. 60 .

47 Wiadomości potoczne, „Dziennik Bydgoski” 1913, nr 133, s. [3].

48 Polska, „Gazeta Codzienna” 1913, nr 224, s. [2]; Wiadomości miejscowe i prowincjonalne , „Postęp” 1913, nr 225, s. [3]; Wiadomości z naszych i dalszych stron, „Gazeta Grudziądzka” 1913, nr 117, s. [2]; Wiadomości potoczne, „Pielgrzym” 1913, nr 117, s. [2].

49 AP Poznań, PP, sygn. 3787: wycinek z „Gazety Świeckiej” 1914, nr 35. 
Kolejna sprawa związana była z setną rocznicą śmierci pod Lipskiem księcia Józefa Poniatowskiego, którą prasa polska postanowiła uczcić, wydając jubileuszowe numery swych pism. Również „Gazeta Świecka” 18 października 1913 r. w numerze 124 oraz numerach 48 „Gazety Chełmińskiej” i „Gazety Chełmżyńskiej” opublikowała teksty dotyczące tego wydarzenia. Szczególnie niebezpieczny okazał się wiersz Pierre Jean Berangera zatytułowany Poniatowski, który zdaniem prokuratury ${ }^{50}$ mógłby „wielkie rozruchy wywołać w granicach państwa pruskiego i naruszyć spokój publiczny obywateli pruskich"51. Pierwsze posiedzenie sądu odbyło się w Grudziądzu 23 marca 1914 r., odroczono je jednak ${ }^{52}$, aby poznać stanowisko prokuratury poznańskiej, która przeprowadziła już dwa postępowania sądowe w sprawie tego samego wiersza ${ }^{53}$. Po raz drugi sąd zebrał się 22 kwietnia. Obrońcą oskarżonego Zielińskiego był znany grudziądzki adwokat Stefan Łaszewski, broniący wielu redaktorów w ich licznych procesach prasowych. Sąd uznał redaktora odpowiedzialnego winnym i skazał go na karę finansową wynoszącą 100 marek lub 20 dni więzienia. Nakazano też konfiskatę wszystkich zachowanych jeszcze w redakcji i drukarni numerów „Gazety Świeckiej” oraz jej mutacji „Gazety Chełmińskiej” i „Gazety Chełmżyńskiej” ${ }^{54}$, co policja wyegzekwowała 9 maja, nic jednak nie znaleziono ${ }^{55}$.

Dnia 12 maja 1914 r. na łamach „Gazety Chełmińskiej” poinformowano, że w ciągu roku nałożono na redaktora około 800 marek kar i kosztów sądowych ${ }^{56}$, co dowodzi, że oprócz dwóch przedstawionych procesów redaktor musiał mieć, nieznany nam dziś, jeszcze trzeci, kosztowniejszy od tego za wiersz o Poniatowskim.

50 Prokurator w oskarżeniu wykorzystał $§ 130$ Kodeksu karnego. Tamże: wyrok sądu z 22 kwietnia $1914 \mathrm{r}$.

51 Tamże: wycinek z „Gazety Świeckiej” 1914, nr 35.

52 Tamże.

53 Redakcją, która opublikowała również wiersz Berangera był „Dziennik Kujawski”. Zob. Polska, „Gazeta Toruńska” 1913, nr 249, s. [2]. Nie skazano jednak redaktora odpowiedzialnego tej gazety i zniesiono konfiskatę numeru. Wiadomości miejscowe i prowincjonalne, „Postęp” 1914, nr 10, s. [3].

${ }^{54}$ AP Poznań, PP, sygn. 3787: wycinek z „Gazety Świeckiej 1914, nr 48; Wiadomości potoczne, „Dziennik Bydgoski” 1914, nr 93, s. [3].

55 AP Poznań, PP, sygn. 3787: wycinek z „Gazety Chełmińskiej” 1914, nr 57; Z różnych stron, „Dziennik Poznański” 1914, nr 111, s. [3-4]; Wiadomości potoczne, „Dziennik Bydgoski" 1914, nr 108, s. [3].

56 AP Poznań, PP, sygn. 3787: wycinek z „Gazety Chełmińskiej” 1914, nr 57. 
Ostatnią gazetą, redaktor której miał kłopoty z niemieckim prawem, był „Głos Lubawski”. Pismo to od pierwszego numeru redagował J. A. Gawrych. Wydaje się, że nie praca w lubawskim wydawnictwie była największym kłopotem redaktora, ale jego wypowiedzi na wiecach i zebraniach, gdzie występował w imieniu redakcji, co było dość powszechnym zjawiskiem w ówczesnym życiu politycznym. W październiku $1913 \mathrm{r}$. Izba Karna w Lubawie skazała go na karę 20 marek lub 4 dni więzienia za przekroczenie $\S \S 12$ i 19 ustawy o stowarzyszeniach i zebraniach. Gawrych na zebraniu zwołanym z okazji rocznicy ogłoszenia Konstytucji 3 Maja przemawiał po polsku, a informacji o organizowanym spotkaniu nie zgłosił policji. Redaktor po ogłoszeniu wyroku poinformował, że odwoła się od tej decyzji sądu, ale brak jakichkolwiek informacji, aby do tego doszło ${ }^{57}$. Kilka dni później za podobne przestępstwo skazano go na kolejne 4 dni więzienia ${ }^{58}$. Gawrych wkrótce trafił do wojska i tam miał dalsze kłopoty z niemieckim wymiarem sprawiedliwości.

Proces drugiego redaktora odpowiedzialnego „Głosu Lubawskiego” W. Ujmy miał inny charakter niż wszystkie wymienione dotychczas. Był wynikiem artykułu ogłoszonego w okresie wyborów uzupełniających do parlamentu niemieckiego z okręgu susko-lubawskiego w styczniu 1914 r., którym obrażony poczuł się Polak - kandydat na posła Leonard Raszkowski z Krzemieniewa. Redakcja „Głosu” zarzuciła mu, że „przyczynił się do zaprzepaszczenia majątku p. [Mieczysława - uzup. autorki] Żuralskiego położonego w Krzemieniewie i że za pośrednictwo swoje suto się obłowił”59. Nazwano go też „sprzedawczykiem” i „zdrajcą sprawy narodowej" 60 . Raszkowski, który przegrał wybory, do czego niewątpliwie przyczyniła się redakcja "Głosu Lubawskiego”, w lutym 1914 r. na łamach „Gazety Toruńskiej”, „Kuriera Poznańskiego” i „Pielgrzyma” zamieścił sprostowanie i ogłosił, że wytoczy proces redakcji lubawskiej gazety ${ }^{61}$.

57 Polska, „Gazeta Toruńska” 1913, nr 232, s. [1]; Wiadomości miejscowe i prowincjonalne, „Postęp” 1913, nr 232, s. [3]; Polska, „Przyjaciel” 1913, nr 121, s. [1].

58 Wiadomości miejscowe i prowincjonalne, „Postęp” 1913, nr 237, s. [3].

59 Sprawa p. Raszkowskiego przed sq̨dem lubawskim, „Dziennik Bydgoski” 1914, nr 157, s. [1].

${ }^{60}$ O nieskazitelność kandydata poselskiego, „Dziennik Bydgoski” 1914, nr 158, s. [1].

61 Polska, „Gazeta Toruńska” 1914, nr 39, s. [1-2]; Nasze sprawy, „Kurier Poznański” 1914, dod. do nr 39, s. [5]; Wiadomości potoczne, „Pielgrzym” 1914, nr 23, s. [2]. 
W trakcie procesu o obrazę, który odbył się 9 lipca, Raszkowskiego reprezentował mecenas Bolesław Kurzętkowski, Ujmę bronił adwokat Manthey. Wszyscy świadkowie poświadczyli rzetelność działań obrażonego, a sędzia zaproponował ugodę, na co zgodziły się strony ${ }^{62}$. Raszkowski cofnął skargę, a Ujma zobowiązał się zamieścić w „Głosie Lubawskim”, „Gazecie Toruńskiej”, „Gazecie Grudziądzkiej” i „Kurierze Poznańskim” oświadczenie: „Podniesione na podstawie błędnych informacji przeciwko kandydatowi na posła do parlamentu, p. Raszkowskiemu z Krzemieniewa, zarzuty, jakoby był sprzedawczykim i jakoby za to otrzymał sute prowizje, odwołuję niniejszym z wyrazem ubolewania"63. Oświadczenia tego nie udało się odnaleźć w żadnej z wymienionych gazet. Być może informację o ugodzie z treścią oświadczenia uznano za jego ogłoszenie, bądź wybuch pierwszej wojny światowej i obecność Ujmy na innym terenie przyczyniły się do zapomnienia urazów.

Podsumowując. Udało się odnaleźć informacje o kłopotach z niemieckim prawem czterech redakcji gazet utworzonych w początkach XX w. na terenie Pomorza Gdańskiego. Redaktorom odpowiedzialnym tych pism wytoczono łącznie 11 procesów ${ }^{64}$ (nie wiadomo, jak skończyły się uwagi policjanta na temat napisu na budynku „Gazety Chojnickiej”). Przed sądem znalazło się siedmiu redaktorów odpowiedzialnych: Alojzy Bieliński, Feliks Kisielewski, Edmund Rakowski, Leon Kowalski, Teofil Zieliński, Józef Alojzy Gawrych oraz Wiktor Ujma. Podobnie jak w gazetach z tradycją, ukazujących się przez całe dziesięciolecia, redaktorzy prowincjonalni najczęściej odpowiadali za obrazę, oskarżeni na podstawie paragrafów 185-187 (Bieliński, Kowalski, Ujma). Groźne skutki powodowało naruszenie § 130 mówiącego o podburzaniu do gwałtów (Zieliński). Najwyższy wyrok zapadł w Starogardzie Gdańskim, gdzie redaktora Bielińskiego skazano na karę finansową wynosząca aż 600 marek, najłagodniej zakoń-

${ }^{62}$ Wiadomości miejscowe i prowincjonalne, „Postęp” 1914, nr 159, s. [3]; Kronika sq̨dowa, „Dziennik Poznański” 1914, nr 157, s. [3]; Sprawa p. Raszkowskiego..., s. [2]; O nieskazitelność..., s. [1]; O nieskazitelność kandydata poselskiego, „Gazeta Toruńska” 1914, nr 158, s. [1].

${ }^{63}$ Sprawa p. Raszkowskiego..., s. [2]; Nasze sprawy, „Kurier Poznański” 1914, nr 157, s. [3].

${ }^{64}$ Jest to liczba procesów, jaką udało się odnaleźć. Być może było ich więcej, o czym nie informowały polskie gazety, a brak źródeł uniemożliwia rzeczywiste ustalenie ich liczby. 
czyła się sprawa redaktora Ujmy, gdy podczas procesu w Lubawie doszło do ugody. Najdłużej ukazująca się, spośród przedstawianych, „Nasza Gazeta" poniosła też największe koszty w relacjach z niemieckim wymiarem sprawiedliwości. Łącznie redaktorzy musieli zapłacić co najmniej 950 marek, kolejne miejsce zajęła „Gazeta Świecka” - 800 marek.

W procesach wytoczonych redaktorom odpowiedzialnym zaprezentowanych gazet odnaleźć można wszystkie cechy charakterystyczne dla konfliktów z prawem innych polskich periodyków ukazujących się w tym czasie w zaborze pruskim:

- jeden proces wywoływał drugi,

- sąd wyrokował więcej niż żądał prokurator,

- powodem procesu był artykuł, który pojawił się w innych gazetach i redaktor odpowiedzialny poniósł konsekwencje podobnie jak inni jego koledzy,

- dominowały te same paragrafy,

- nie obeszło się bez konfliktu polsko-polskiego, na szczęście w tym wypadku zakończonego ugodą.

Oczywiście cały czas trzeba pamiętać, że prezentowane gazety nie zachowały się, a informacje o ich relacjach z policją, prokuraturą i sądami niemieckimi posiadamy przede wszystkim ze źródeł pośrednich, co nie pozwala z całą stanowczością stwierdzić, że przedstawione procesy były jedynymi, jakie periodykom tym wytoczono.

\section{Legal troubles of the forgotten Pomeranian newspapers}

(1910-1915)

ABSTRACT: In the early twentieth century, the number of newspapers offered to the West Prussia Polish community increased significantly. In smaller towns, outside Gdańsk, Toruń and Grudziądz, numerous newspapers were launched. Their target audience were residents of Starogard, Chojnice, Świecie and Lubawa and the surrounding villages. The newspapers published information regarding the country, province, region and nearest towns. However, the editorial staff of "Nasza Gazeta”, "Gazeta Chojnicka”, “Gazeta Święcka” and "Głos Lubawski” soon faced serious legal trouble with the German justice. Cases against the editors-inchief of these periodicals were brought to court 11 times. During the trials the 
editors were accused of insults and violence incitement. As a result, they were fined with nearly two thousand marks of financial penalty. Seven editors were brought to court for trial.

KEYwords: “Gazeta Chojnicka”, “Gazeta Święcka”, "Głos Lubawski”, "Nasza Gazeta”, 1910-1915, Pomeranian newspapers, press offences. 